\title{
ПРАВОВАЯ ОЦЕНКА МЕДИЦИНСКОГО ВМЕШАТЕЛЬСТВА В ОТНОШЕНИИ ЗДОРОВОГО ЧЕЛОВЕКА
}

\author{
(c) 2019 Хавжокова Залина Борисовна \\ кандидат юридических наук, доцент \\ Кабардино-Балкарский Государственный Университет, Россия, КБР, Нальчик \\ E-mail: rado10101@rambler.ru \\ (c) 2019 Зумакулова Зарема Ахматовна \\ кандидат юридических наук, доцент \\ Кабардино-Балкарский Государственный Университет, Россия, КБР, Нальчик \\ E-mail: zarema.zum@mail.ru \\ (c) 2019 Карамурзова Инна Барасбиевна \\ кандидат юридических наук, доцент \\ Кабардино-Балкарский Государственный Университет, Россия, КБР, Нальчик \\ E-mail:07innka@mail.ru \\ (c) 2019 Кокова Диана Аслановна \\ кандидат юридических наук, доцент \\ Кабардино-Балкарский Государственный Университет, Россия, КБР, Нальчик \\ E-mail:d.kokova@yandex.ru \\ (c) 2019 Бейтуганова Залина Хажмуратовна \\ старший преподаватель \\ Кабардино-Балкарский Государственный Университет, Россия, КБР, Нальчик \\ E-mail: beituganova7890@gmail.com
}

Данная статья посвящена вопросу правовой оценки медицинского вмешательства в отношении здорового человека, в частности исследованию правовой регламентации трансплантации органов и тканей человека, а также производства медицинского эксперимента.

Ключевые слова: здоровье человека, трансплантация органов, медицинское вмешательство, донорство, медицинский эксперимент.

В настоящее время в условиях стремительного развития медицинской науки, появления новых методов диагностики и лечения, развития научно-технической мысли в области медицины актуальным становится вопрос о правовой оценке медицинского вмешательства в отношении здорового человека.

При этом наиболее значимым является правовая регламентация трансплантации органов и тканей человека, а также производства медицинского эксперимента [1].

Правовое регулирование трансплантации органов и тканей человека осуществляется на основе Закона РФ «О трансплантации органов и (или) тканей человека» от 22 декабря 1992 года. В теории уголовного права проблему правомерности причинения вреда при трансплантации рассматривают параллельно с вопросом и пра- вомерности донорства крови.

В частности, в качестве критериев правомерности донорства крови и трансплантации органов и тканей И.Л. Горелик и А.Н. Красиков выделяют следующее условия:

1) больному нельзя оказать помощь иными средствами, кроме пересадки органов и тканей;

2) вред, причиняемый при этом донору, меньший, чем предотвращенный вред для больного-реципиента [2].

В настоящее время в связи с бурным развитием трансплантологии юридическая практика разработала ряд условий, при соблюдении которых действия врачей при изъятии крови и ее компонентов, а равно органов и тканей у доноров следует признавать правомерными.

В частности, критерии правомерности донорства крови и ее компонентов логически вы- 
текают из положений Федерального закона «О донорстве крови и ее компонентов» от 20 июля 2012 г.

В их числе следующие условия:

1) донорство крови и ее компонентов есть свободно выраженный добровольный акт;

2) донором вправе быть дееспособное лицо, являющееся гражданином Российской Федерации либо проживающим на территории Российской Федерации на законных основаниях не менее одного года иностранным гражданином или лицом без гражданства, достигшее возраста восемнадцати лет или приобретшее полную дееспособность до достижения им возраста восемнадцати лет в соответствии с законодательством Российской Федерации, изъявившее добровольное желание сдать кровь и (или) ее компоненты, прошедшее добровольно медицинское обследование и не имеющее медицинских противопоказаний для сдачи крови и (или) ее компонентов;

3) взятие от донора крови и ее компонентов допустимо только при условии, если здоровью донора не будет причинен вред;

4) запрещена продажа донорской крови ее компонентов и препаратов из донорской крови в другие государства в целях извлечения прибыли.

Практически тождественные условия характеризуют правомерность трансплантации органов и тканей человека. Особенностью, пожалуй, является только то, что в Законе «О трансплантации органов и (или) тканей человека» содержится специальное указание, согласно которому изъятие органов не допускается у лица, находящегося в служебной или иной зависимости от реципиента (ст. 3). Более того, донор должен свободно и сознательно в письменной форме выразить согласие на изъятие своих органов и (или) тканей.

В случае изъятия органов и тканей в отсутствии письменного согласия донора либо у донора, не достигшего установленного возраста, медицинский работник подлежит уголовной ответственности за умышленное причинение тяжкого вреда здоровью, поскольку, согласно ст. 111 УК РФ, потеря какого-либо органа является признаком тяжкого вреда.

В теории и практике уголовного права актуальным является также вопрос о пределах правомерности проведения с согласия лица медицинского эксперимента. Как справедливо отмечает
Ф.Ю. Бердичевский, «эксперимент - это весьма существенная сфера медицинской деятельности, которую уголовному праву нельзя не учитывать, поскольку на практике любое экспериментирование над человеком стоит вне закона» [3].

Пытаясь определить условия правомерности экспериментирования, М.Д. Шаргородский еще в 1948 году отмечал, что «при рассмотрении вопроса о вреде, причиненном врачом в результате применения новых методов лечения, следует исходить из того, что экспериментирование является необходимым в области медицины. Однако для применения нового лечебного средства или метода к больному должно быть получено согласие последнего или его законных представителей, т.е. для экспериментирования должны быть, во всяком случае, признаны действующими те правила, которые имеют место в отношении хирургических операций. Если согласия больного его законных представителей получено не было, а результатом эксперимента явилась смерть или вред здоровью пациента, врач может отвечать как за неосторожное преступление против жизни и здоровья, так и за преступление, совершенное с эвентуальным умыслом» [4].

Рассматривая условия правомерности причинения вреда здоровому человеку в порядке медицинского эксперимента, следует отметить, что в теории уголовного права данная проблема не получила однозначного разрешения. Более того, с закреплением в числе обстоятельств, исключающих преступность деяния, обоснованного риска, возникли трудности в разграничении данных уголовно-правовых институтов.

Так, например, М.Н. Малеина выделяет следующие условия правомерности производства эксперимента:

1) полная предварительная информация о предстоящем эксперименте (необходимость предоставления полной информации о целях, методах, продолжительности, ожидаемом результате, побочном эффекте и другом возможном риске);

2) свободное письменное согласие гражданина-объекта исследования (во имя исключения скрытых форм принуждения вводится запрет проведения биомедицинских исследований с привлечением в качестве объекта лиц, задержанных, заключенных под стражу, отбывающих наказание в местах лишения свободы либо заключенных под административный арест);

3) предварительное проведении лабора- 
торного эксперимента (научная обоснованность эксперимента, подтверждаемая разработанной методикой (оформленной протоколом или другим документом), показаниями медицинских приборов, кино-, фотоаппаратурой, иной техникой либо показаниями свидетелей или наблюдателей);

4) осуществление эксперимента в учреждении государственной или муниципальной системы здравоохранения (либо под контролем этих учреждений, когда речь идет о проведении исследования в космосе, под землей, под водой и т.п.) [5].

На международном нормативном уровне вопросы правомерности медицинского экспериментирования регламентированы в Нюрнбергском кодексе. На основании данного документа можно выделить следующие непременные условия проведения экспериментов на людях:

1. Эксперимент должен приносить обществу положительные результаты, недостижимые другими методами или способами исследования; он не должен носить случайный, необязательный по своей сути характер.

2. Эксперимент должен основываться на данных, полученных в лабораторных исследованиях на животных, знании истории развития данного заболевания или других изучаемых проблем. Его проведение должно быть так организовано, чтобы ожидаемые результаты оправдывали сам факт его проведения.

3. При проведении эксперимента необходимо избегать всех излишних физических и психических страданий и повреждений.

4. Ни один эксперимент не должен проводиться в случае, если «а priori» есть основания предполагать возможность смерти или инвалидизирующего ранения испытуемого; исключением, возможно, могут являться случаи, когда врачи-исследователи выступают в качестве испытуемых при проведении своих экспериментов.

5. Степень риска, связанного с проведением эксперимента, никогда не должна превышать гуманитарной важности проблемы, на решение которой направлен данный эксперимент.

6. Эксперименту должна предшествовать соответствующая подготовка, и его проведение должно быть обеспечено оборудованием, необходимым для защиты испытуемого от малейшей возможности ранения, инвалидности или смерти.
7. Эксперимент должен проводиться только лицами, имеющими научную квалификацию. На всех стадиях эксперимента от тех, кто проводит его или занят в нем, требуется максимум внимания и профессионализма.

8. В ходе проведения эксперимента испытуемый должен иметь возможность остановить его, если, по его мнению, его физическое или психическое состояние делает невозможным продолжение эксперимента.

9. В ходе эксперимента исследователь, отвечающий за его проведение, должен быть готов прекратить его на любой стадии, если профессиональные соображения, добросовестность и осторожность в суждениях, требуемые от него, дают основания полагать, что продолжение эксперимента может привести к ранению, инвалидности или смерти испытуемого.

10. Однако самым необходимым условием проведения эксперимента на человеке является добровольное согласие последнего. Это означает, что лицо, вовлекаемое в эксперимент в качестве испытуемого, должно иметь законное право давать такое согласие; иметь возможность осуществлять свободный выбор и не испытывать на себе влияние каких-либо элементов насилия, обмана, мошенничества, хитрости или других скрытых форм давления или принуждения; обладать знаниями, достаточными для того, чтобы понять суть эксперимента и принять осознанное решение. Последнее требует, чтобы до принятия утвердительного решения о возможности своего участия в том или ином эксперименте испытуемый был информирован о характере, продолжительности и цели данного эксперимента, о методах и способах его проведения; обо всех предполагаемых неудобствах и опасностях, связанных с проведением эксперимента, и. наконец, возможных последствиях для физического или психического здоровья испытуемого, могущих возникнуть в результате его участия в эксперименте. Обязанность и ответственность за выяснение качества полученного согласия лежит на каждом, кто инициирует, руководит или занимается проведением данного эксперимента. Это персональная обязанность и ответственность каждого такого лица, которая не может быть безнаказанно переложена на другое лицо.

Что же касается национального законодательства, то оно в более общих чертах регламентирует проблему, связанную с согласием па- 
циента. В частности, предполагается, что лицо должно иметь полную предварительную информацию о целях, методах, продолжительности, ожидаемом результате, побочном эффекте и другом возможном риске производства эксперимента (ст. 43 Основ законодательства об охране здоровья граждан). Об обязательном наличии добровольности, своевременности и конкретности обязательность свободного, предварительного и письменного согласия лица - объекта эксперимента.

Нерешенным остается вопрос относительно законодательного закрепления действительности согласия. Широкий спектр поставленных перед медицинским экспериментированием задач не позволяет нормативно ограничить возраст объектов исследования.

В этой связи возможна следующая уголовно-правовая оценка деяний: если тяжкий вред или вред средней тяжести причинены вменяемому лицу, достигшему возраста 16 лет, с его согласия при производстве эксперимента - деяние следует оценивать по правилам обоснованного риска, а при отсутствии признака действительности согласия - по правилам об умышленном причинении вреда здоровью или жизни пациента.

В настоящее время в условиях стремительного развития медицины существующая практика квалификации деяний, выходящих за рамки правомерности экспериментирования, себя не оправдывает. Трудно признать справедливой ситуацию, когда при наличии четко обозначенных условий правомерности не обозначены пределы уголовной противоправности экспе- риментирования. Практика оценки действий медицинских работников в этой сфере не может более ограничиваться правилами о производстве действий с согласия потерпевшего (особенно при отсутствии формального закрепления этого института) или условиями обоснованного риска.

В современных условиях своевременным видится внесение ряда изменений в уголовное законодательство, в частности, введение в него новой нормы ст. 120.1 «Незаконное экспериментирование на людях» следующего содержания:

«1. Незаконное проведение биомедицинских или иных экспериментам над лицом без его согласия,- - наказывается...

2. То же деяние, если оно повлекло по неосторожности смерть лица либо причинение тяжкого вреда здоровью,- ....».

Подобная законодательная конструкция позволит решить ряд теоретически и практически значимых задач.

Во-первых, будут очерчены границы уголовной противоправности медицинского экспериментирования на людях.

Во-вторых, на нормативном уровне будет урегулирован вопрос о волеизъявлении объекта экспериментирования.

B-третьих, введение данной нормы снимет вопрос о квалификации действий, причинивших смерть либо тяжкий вред здоровью пациента. В случае, если неблагоприятные последствия охватывались умыслом экспериментатора - налицо умышленное причинение вреда здоровью или жизни (ст. 105, 111, 112, 115), а при неосторожном отношении - ч. 2 ст. ст. 120.1 .

\section{Библиографический список}

1. Х Хавжокова З.Б.; Зумакулова З.А.; Карамурзова И.Б.; Бейтуганова З.Х. Пределы правомерности причинения вреда при медицинском вмешательстве. // Вопросы экономики и права. М., 2019. С.12.

2. Горелик И.И. Правовые аспекты пересадки органов и тканей. Минск, 1971; Красиков А. Н. Указ. соч. С. 84.

3. Шаргородский М.Д. Преступления против жизни и здоровья. М., 1948. С. 228.

4. Малеина М.Н. Личные неимущественные права граждан: понятие, осуществление, защита. М.,2001.С. 81.

5. Бердичевский Ф. Ю. Уголовная ответственность медицинского персонала за нарушение профессиональных обязанностей. М., 1970. 